Arhe XVII, 33/2020

UDK 159.964.2 Lacan J.

DOI https://doi.org/10.19090/arhe.2020.33.267-288

Originalni naučni rad

Original Scientific Article

\author{
MAJA MILIĆ ${ }^{1}$ \\ Beograd
}

\title{
OSNOVNE TEZE KONCEPTA NARCISTIČKOG ISKRIVLJENJA
}

Sažetak: U radu su ponuđene osnovne teze koncepta narcističkog iskrivljenja, koje može ići u dva smera - objašnjeno je formiranje i iskustvo koje subjekat može imati u takozvanim konkavnim i konveksnim narcističkim ogledanjima. Teorija se umnogome oslanja na Lakanovo viđenje stadijuma ogledala, kao i na njegov doprinos razvijanju subjekta samosvesti kroz konstitutivno-imaginarne dimenzije subjektivnosti. U slučaju umetnutog konkavnog ili konveksnog iskrivljenja, subjekat nalazi sebe na mestu drugog, poistovetivši se sa svojim iskrivljenim ogledalnim odrazom u drugom. Iskrivljenja utiču na formiranje subjekta u nastajanju na vrlo konkretan način i prenose predispoziciju za određene nestabilnosti u potonjim ogledanjima. Rad je ilustrovan studijom slučaja koja ima za cilj lakše razumevanje ponuđenog pristupa. Takođe, dat je kritički osvrt na mogućnost formiranja ravne ogledalne površina, kao i detaljno određenje konveksnog iskrivljenja i četiri pozicije konkavnog narcističkog ogledanja.

Ključne reči: psihoanaliza, Lakan, stadijum ogledala, iskrivljenje narcističkog ogledanja

Proces formiranja subjekta u nastajanju posredstvom stadijuma ogledala do sada je mnogo puta ispričan ${ }^{2}$. Prvenstveno, mislim na Lakana

\footnotetext{
${ }^{1}$ E-mail adresa autorke: milicmaja21@gmail.com

${ }^{2}$ Vidi: Lacan, J., „The Mirror Stage as Formative of the I Function as Revealed in Psychoanalytic Experience“, Ecrits, W. W. Norton \& Company, New York, 2006, p. 93-100.
} 
i Vinikota ${ }^{3}$, te Polinu Kernberg ${ }^{4}$. Ipak, čitajući tekst koji sledi, pre svega, važno je imati na umu Lakanovu teoriju ${ }^{5}$. Na prvom mestu, njegovo viđenje konstitutivno-imaginarne, ogledalne, dimenzije subjektivnosti.

Kada subjekat u nastajanju biva imaginarno konstituisan oslanjajući se u ogledalnom, tj. odraznom liku a', pretpostavka je da se taj odraz nalazi na refleksiji ravne ogledalne površine. Međutim, pitanje je, šta bi se desilo, ili još preciznije šta se dešava kada se ogledalni proces ne odigrava po principu ravnog ogledala? Ukoliko je po sredi određen deformitet, ili čak malformitet, ta situacija postaje relevantna kako za teoriju tako i za samu kliničku praksu. Drugim rečima, kao suštinsko, postavlja se pitanje eventualne premorbidne strukture ogledalnog drugog.

Efekat $\mathrm{u}$ tom slučaju neizbežnih iskrivljenja biva očigledan $\mathrm{u}$ ogledalnom liku $a$ '. Subjekat u nastajanju je imaginarna refleksija ogledalnog lika, tj. narcističkog objekta malo a. Otud, logično je za pretpostaviti, sve moguće torzije i distorzije ogledalnog lika ne mogu biti bez efekta na proces konstituisanja samog subjekta u nastajanju.

Iskrivljenja o kojima govorim mogu ići u smeru ispupčenja ili udubljenja. U smeru konveksnosti ili konkavnosti narcističkog ogledanja. Narcistička relacija je relacija ogledanja. Kao takva ona genealoški prethodi svakoj mogućoj projekciji ${ }^{6}$. Ona utiču na ličnost subjekta u

\footnotetext{
${ }^{3}$ Winnicott, D. W., Mirror-role of the mother and family in child development, in Playing and Reality, Psychology Press, Hove, 2005, p. 149-159.

${ }^{4}$ Kernberg, P., Beyond the Reflection: The role of the mirror paradigm in clinical practice, Other Press, New York, 2007.

${ }^{5}$ Takođe, na ovom mestu se mogu pomenuti savremeniji autori koji doprinose lakšem razumevanju teze koja će u radu biti predstavljena. Vidi: Bursztein, J-G., Subjective Topology: A Lexicon, Hermann Editeurs Des Sciences Et Des Arts Sa, Paris, 2019. Od istog autora: Bursztein, J-G., The Unconscious, its Space-Time: Aristotle, Lacan, Poincaré, Hermann Editeurs Des Sciences Et Des Arts Sa, Paris, 2020. Takođe: Greenshields, W., Writing the Structures of the Subject: Lacan and Topology (The Palgrave Lacan Series), Palgrave Macmillan, London, 2018. Dalje: Friedman, M. and Tomsic, S., Psychoanalysis: Topological Perspectives: New Conceptions of Geometry and Space in Freud and Lacan, Transcript Verlag, 2017. I na kraju: Ragland, E. and Milovanovic, D., Lacan: Topologically Speaking, Other Press, New York, 2004.

6 Jevremović, P., Psihoanaliza $i$ ontologija, Zavod za udžbenike i nastavna sredstva, Beograd, 1988, str. 97.
} 
nastajanju na vrlo konkretan način i prenose predispoziciju za određene nestabilnosti. U najekstremnijem smislu na taj način možemo razumeti i psihotični potencijal, koji u manjoj ili većoj meri imaju svi, ali sa velikom razlikom u njegovoj spremnosti da se iskaže.

$$
* * *
$$

Stepen ili tip mogućnosti iskrivljenja ogledala, u kojem se subjekat u nastajanju svog narcističkog jezgra ogleda, upravo govori o (ne)stabilnosti i raz-uobručenosti samog brigujućeg objekta. Ogledalo, kao što znamo može biti (manje ili više) ispupčeno ili izdubljeno, tj. konveksno i konkavno. Mogući tip ogledala (ravno, konveksno, konkavno) možemo posmatrati kao model konstituisanja objektnog odnosa.

Da bi od početka bila jasna teza koju želim da predstavim, počnimo od samog početka sa ravnim ogledalom. Kao što u životu to biva, određena psihopatološka stanja brigujućeg drugog ne podrazumevaju postojanje egzaktne verovatnoće (tj. nužnosti) kakvu će strukturu ili psihopatologiju imati subjekat u nastajanju, ali podrazumeva određene (moguće) pravce u kojima možemo očekivati određen razvoj narcističkog jezgra.

Vratimo se stadijumu ogledala i ilustraciji koju je ponudio Lakan njegovom poznatom L shemom ${ }^{7}$. Setite se, u igri je obeleženo $S$ našeg subjekta $u$ nastajanju, ili kako je to Lakan voleo da naglasi subjekat $u$ otuđenju ${ }^{8}$. Zatim imamo, objekat malo a, koji predstavlja imago ili sliku brigujućeg drugog. I na kraju, $a^{\prime}-$ refleksiju ogledalnog lika. Dešava se

\footnotetext{
${ }^{7}$ Lakan u svojim Seminarima predstavlja L shemu, koja olakšava razumevanje puta koji subjekat prelazi kroz stadijum ogledala. Vidi: Lacan, J., „The Ego in Freud's Theory and in the Tehnique of Psychoanalysis“, The Seminar of Jacque Lacan, Book II, . Cambridge, 1988, p. 243.

${ }^{8}$ Smisao fantazma ogleda se u zadobivanju bazične pozicije koja istrajava na uverenju da, poistovetivši se sa afektivno visoko investiranim drugim, subjekat postaje (kao) taj isti drugi. Sa njim se poistovećuje. U sebe ga unosi. Tačnije u sebe unosi predstavu, imago, njega kao idealnog drugog (...) Poistovećivanje u izvesnom smislu na taj način predstavlja otuđenje. Na neki način subjekat $u$ nastajanju tu sebe zameni drugim (Jevremović, P., Psihoanaliza i ontologija, str. 104-105).
} 
prelamanje. Dešava se ogledanje. Dešavaju se projekcije $e^{9}$ U osnovi, ovo je proces preverbalnog perioda, nesvesnih pulzija, fantazama ${ }^{10}$. Svih sadržaja koji će nepovratno odrediti potonje interakcije i naknadna ogledanja. Sudbina samog subjekta na ovaj način biva primarno konstituisana.

Na koji način ogledalni drugi može svojim iskrivljenjem da utiče na proces formiranja subjekta samosvesti ${ }^{11}$ ? Ukoliko u samom liku u kojem se subjekat ogleda nema stabilne strukture i funkcionalnosti, to dovodi do raz-obručenja ${ }^{12}$ subjektovog narcističkog, a primarno svakako fragilnog, jezgra. U zavisnosti od intenziteta i kvaliteta disfunkcionalnosti efekta ogledalnog lika, zavisiće stepen potonjih iskrivljenja u kojima će se subjekat ogledati. Ali ne samo ogledati, već i poistovetiti ${ }^{13}$, a time i težiti da se u odnosu prema istom centrira. Narcistički subjekat se, dakle, može investirati i deinvestirati. $\mathrm{U}$ tom slučaju, svaka inicijalna (narcistička) investicija i deinvesticija dolazi sa mesta drugog.

Investicija brigujućeg drugog prodire u polje inicijalne rasutosti subjekta u nastajanju, time se konstituiše imaginarni predložak potonjeg subjekta koji govori, od onog trenutka kada postane deo simboličkog poretka. To prodiranje, ta imaginarna intruzija drugog, nikad nije ravnomerna. Izvesna iskrivljenja uvek postoje.

Teorijski, ravna površina ogledala je svakako moguća, ali aktualno je neodrživa. Haos i destrukcija nisu isključivo dimenzije rane

9 Između narcističkog subjekta i narcističkog objekta događa se, dakle, kongruencija, preklapajuće-preslikavanje. Za Lakana to bi bio smisao stadijuma ogledala (Jevremović, P., Lakan i psihoanaliza, Plato, Beograd, 2000, str. 100).

${ }^{10}$ Smisao fantazama je u preklapanju (odnosno, on bi se uvek kretao u sferi preklapanja) nečeg uvek manjkovitog, ontološki zakinutog, sa nečim pretpostavljeno celovitim, totalnim (...) Svaki fantazam u svojoj osnovi podrazumeva relaciju, ili još bolje tenziju, između ne-celog i celog, između parcijalnog i totalnog (Jevremović P., Lakan i psihoanaliza, str. 101).

${ }^{11}$ Hegel u Fenomenologiji duha objašnjava da samosvest postoji za sebe iznajpre samo kao ta prosta suština i za predmet ima sebe kao čisto Ja (Hegel, G.V. F., Fenomenologija duha, BIGZ, Beograd, 1974, str. 109).

12 Jevremović, P., Inverzija stadijuma ogledala, u Hermeneutički triptih, Gramatik, Beograd, 2019, str. 143-155.

${ }^{13}$ Smisao narcističkog poistovećenja na nivou fundamentalnog fantazma, prema Lakanu, leži u otuđivanju od sebe, kada subjekat u nastajanju sebe zameni drugim (Jevremović, P., Psihoanaliza i ontologija, str. 105). 
subjektivnosti. Isto važi i za brigujućeg drugog, za (primarni, narcistički) objekat $^{14}$. Očigledno, što su mentalni haos i psihopatološka destrukcija kod samog objekta naglašeniji, to je naglašenije njegovo ogledalno iskrivljenje, koje se nudi subjektu u nastajanju. Kao što je poznato, nema formiranog subjekta (u ovom slučaju subjekat je u funkciji objekta, brigujućeg drugog) koji je bez izvesne nestabilnosti; bez sopstvene shizoparanoidne $^{15}$ istorije; samim tim, i bez iskrivljenja. Naravno, što je ogledalno iskrivljenje manje, to su predispozicije subjekta u nastajanju stabilnije ${ }^{16}$. I obrnuto.

Ravna ogledalna površina subjektu u nastajanju nudi izvesnu mogućnost (fantazmatske) kontrole nad ogledalnim procesom. Udaljavanje subjekta prati udaljavanje ogledalnog lika. Isto važi i za situaciju njegovog približavanja. U oba slučaja, pre svega, moguća je predikcija kretanja drugog. U slučaju da je sam lik nestabilne forme ${ }^{17}$, da ga iznutra potresaju različiti shizoidno-paranoidni procesi i primitivna stanja, tada on, uprkos svemu, zbog visokog stepena kontrole njegovih pokreta, ne biva doživljen kao preplavljujući. U protivnom, nestabilnost objekta, tj. fragilnost njegove strukture i forme, samog bi subjekta u nastajanju (logikom psihopatološkog poistovećivanja) učinila nestabilnim.

${ }^{14}$ Vidi: Lacan, J., „The Ego in Freud's Theory and in the Tehnique of Psychoanalysis“, The Seminar of Jacque Lacan, Book II, str. 4.

${ }_{15}$ Termini teorije objektnih odnosa, psihoanalitičarke Melani Klajn - depresivna i shizo-paranoidna pozicija objašnjeni su između ostalog u Klein, M., Envy and Gratitude and Other Work. A Delta Book, New York, 1977.

${ }^{16}$ Kod konkavnog narcističkog iskrivljenja imamo četiri pozicije koje će biti detaljno opisane nešto kasnije u radu.

${ }^{17} \mathrm{U}$ fizici se ovaj pojam imenuje kao realan, međutim u rečniku psihopatologije i psihoanalize pojam realno ima specifično značenje, te je zato ovde ponuđen termin stabilnost forme. Setimo se na ovom mestu kako je govorio Merlo-Ponti: „Razmatrana merila, na primer, ako ih zaista uzmemo ozbiljno, ne bi trebalo da proteraju sve istine fizike na stranu 'subjektivnog', čime bi bilo očuvano pravo na ideju nepristupačne 'objektivnosti', ali bi trebalo da ospore sam princip ovog rascepa, i da u definiciju 'realnog' uvedu kontakt između posmatrača i posmatranoga“" (Merlo- Ponti M., Vidljivo i nevidljivo, Akademska knjiga, Novi Sad, 2012, str. 26). Dalje, na ovom mestu Merlo- Ponti, dalje govoreći o odnosu nauke i bića, daje aluziju na Hajdegerovu ontologiju, obrazlažući da je pitanje o smislu bića ključno ontološko pitanje (Ibid.). 
Subjekat tada biva isto što i ogledalni lik. Diferencijacija ovde izostaje. Jer kao što vidimo (Slika 1.), subjekat i objekat su simetrični, jednaki po veličini i ogledalni lik prati pomeranje (distanciranje) subjekta. Upravo nestabilnost forme ogledalnog lika, ali i predvidljivost njegovih mogućih pokreta, subjektu obezbeđuje sigurnost od utapanja koje je doživeo Narcis. Dakle, nestabilnost imaginarnog jezgra je na taj način prisutna i kod hipotetičkog ravnog ogledala.

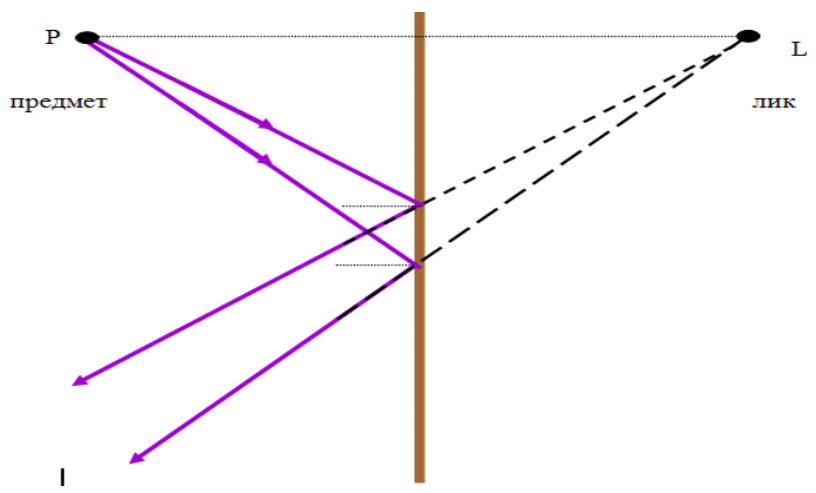

Slika 1.

Kao što vidimo izuzetno je bitan proces distanciranja. Od kapaciteta za udaljavanjem i približavanjem samog brigujućeg drugog na prvom mestu, zavisiće kasnija mogućnost subjekta da procenjuje i sprovodi kretanje $\mathrm{u}$ odnosu na iskrivljenja ogledalnih likova. Ovo kretanje svoje početke ima još u preedipalnom periodu ${ }^{18}$.

Distanca je neophodna, posebno ukoliko se razume da ona nije isto što i odsustvo. Ovde govorimo o distanci sa prisustvom drugog. Jer upravo svojim prisustvom, drugi utiče na iskustvo ogledalnog lika.

${ }^{18} \mathrm{Za}$ bolje razumevanje ovog pojma vidi: Freud, S., "The Ego and the Id and Other Works" in The Dissolution of the Oedipus complex: The Standard Edition of the Complete Psychological Works of Sigmund Freud. Volume XIX, 19231925, 1924, 171-180. 
Navešću jedan primer. Submisivan mlad muškarac (koji je sticajem, za njega, neobičnih životnih okolnosti krenuo na psihoterapiju) želi da bude viđen od strane svoje majke. Majke koja ga je frojdijanski kastrirala $^{19}$, kastrirajući njegovog oca. Mogli bismo da kažemo i tragično kastrirala, jer mladić ima puno drugih kapaciteta. Ipak, on kao da želi samo jedno, da ga majka, njegov brigujući objekat primeti i vidi. Da u ogledalnom liku prepozna prihvatanje i odobravanje. On vapi za njenim prepoznavanjem i validiranjem. Uronjen u prošlost, seća se da je majka jasno verbalizovala razočarenje $\mathrm{u}$ njega, te da danas biva začuđena kako je ispao tako uspešan. A mladić je po svim uobičajnim (socijalnim) standardima izuzetno uspešan. Ipak, to ontološki prazno mesto ga preplavljuje i guši.

Ipak, mladić još uvek gaji jasnu nadu da če ga ona (sveprisutna u svojoj kritikujućoj i neprekidnoj kastraciji), majka, dakle, njegov primarni ogledalni lik, ako uradi još samo ovo, konačno prepoznati $i$ videti; ili barem obratiti pažnju na njega. To uverenje se u različitim oblicima ponovilo toliko puta, da su dovela do zadržavanja i produbljivanje magijskog mišljenja u formi ako-onda. To je, dalje, imalo za posledicu imaginarnu ( $\mathrm{tj}$. narcističku) nestabilnost prilikom fomriranja subjektiviteta mog klijenta.

Nepotrebno je naglasiti da se de-centriranje u pravom smislu te reči još uvek nije desilo. Mladić je i dalje osuđen na fragilnost subjektiviteta sopstvene ličnosti u stalnom ogledanju i zavisnosti. To bi bila paradoksalna, narcistička, privilegija koja mu onemogućava dalji psihološki, psihoterapijski napredak. Stalno preispitivanje sopstvene adekvatnosti koja se dovodi u pitanje zbog neprijatnosti iskustva sa ogledalnim likom. Kao što je rečeno, mladić je profesionalno i finansijski superioran, ali željan ogledalne potvrde, te još uvek nije sam svoje uspehe imao šansu da opazi. Jer, fantazmatski posmatrano, dok ogledalni lik to ne bude semantički oposredovao ništa od navedenog se neće vrednovati u njegovoj percepciji sopstvenog subjektiviteta. Ostaće praznina. Do sada,

\footnotetext{
19 Ibid.
} 
on se još uvek nije narcistički zdravo samo-ogledao, jer ono što on vidi kao refleksiju je omnipotentni odraz kastrirajućeg drugog. U odnosu na njega on doživljava sebe, kao jedini izvor sopstvene istine.

Posredi imamo iskrivljenje narcističke slike i realnosti, videćemo nešto kasnije u tekstu, konkretno konkavno iskrivljenje. Mladićev misaoni tok je uvek crn, uvek pesimističan, uvek nepovratno autodestruktivan. Njegove misli prisilno utiču na doživljaj samovrednovanja i razumevanja situacija u kojima se nalazi. Zbog toga on guši svaku naznaku principa zadovoljstva prenaglašavajući mehanizam racionalizacije kao odbrambeni mehanizam od straha od ludila. Ludila koje mu je toliko strašno da je spreman da depresivno odustane.

Setimo se Lakanovog jouissance ${ }^{20}$ koji je povezan sa zakonom (u smislu normi), pa tako i sa sopstvenom trasgresijom. O trasgresiji užitka on detaljno govori u Seminarima iz 1959-60 godine $^{21}$, a posebno je naglašeno da jouissance predstavlja užitak koji se doživljava kao patnja. Trasgresija principa zadovoljstva postaje bol, jer se tu subjekat susreće sa 'bolnim zadovoljstvom', kako je smatrao Lakan.

Prisilnim radnjama mladić se brani od navirućih sadržaja, koje ga zatim spiralno suočavaju sa strahom od ludila. Ali kao da se u svemu tome nalazi izvestan užitak, jouissance, te se krug krivice iznova i iznova ponavlja. Ritualne radnje su samo maska njegovog sve-preplavljujućeg osećanja tenzične krivice. Jer i on i majka potajno znaju da ju je prevazišao, ako ne u svom znanju i talentu, onda u svojoj mladosti i snazi. Čak i ako njegova zaostavština ne nadživi njenu, on će nadživeti nju. I kao što smo rekli - krivica; ali i užitak kroz jouissance. Odvajanje od preplavljujuće majke formira primarnu krivicu i subjektovo osećanje

${ }^{20}$ Lacan, J., „The Ethics of Psychoanalysis“, The Seminar of Jacques Lacan: Book VII, 1959-60, Routledge, London, 1992, str. 185. (Takođe, ovde je dobro pojasniti da se francuska reč jouissance na engleski može prevesti kao enjoyment, ali francusko značenje ima seksualnu konotaciju (orgazam) za razliku od engleskog prevoda. Zbog toga je često u engleskim prevodima ova reč ostajala neprevedena (Evans, An Introductory Dictionary of Lacanian Psychoanalysis, Routledge, London, 1996, p. 93). Na srpski eventualno možemo prevesti jouissance kao užitak. Takođe, za ovu temu važan je i tekst: Lacan, J. „God and Woman's jouissance“, Encore, W. W. Norton \& Company, New York, 1998, p. 61-77).

${ }^{21}$ Ibid. 
stalnog nedostatka i žudnje ${ }^{22}$ (setimo se ovde Lakanovog otuđenja koje je sudbina formiranja subjektiviteta kroz stadijum ogledala). Brigujući drugi biva deo subjektiviteta, ali je ovo neophodno da bi se subjekat formirao, a zatim i preživeo, tako jouissance postaje deo krivice.

Oceubistvo je teorijski razrađeno, priča o $\operatorname{Edipu}^{23}$ i Laju je toliko puta ispričana da je vremenom gotovo postala deo svakodnevnice. Ipak, majkaubistvo pokreće najdrevnije arhetipe užasa i krivice. Prevazići Oca, prevazići Red, Zakon i Poredak ${ }^{24}$ je gotovo tehnička stvar, uvek očekivana i podržana. Svakako bolna, ali u isto vreme neophodna. Prevazići majku, prevazići ogledalni lik koji je deo otuđenja, koji se odvija u preedipalnom periodu, fantazmatski se graniči sa haosom. S druge strane, to je početak bivanjem i postajanjem subjektom (samo mesto granice od subjekta u nastajanju ka subjektu), otuđenje od sebe samog.

Mogućnost udaljavanja (tj. distanciranja), kao što smo videli, ima ključno mesto u ovoj tezi. Ono će subjektu samosvesti obezbediti tendenciju, težnju ka fantazmatskom uobručavanju, čak i u haotičnim i preplavljujućim okolnostima. Ukoliko se distanciranje onemogući ili još dramatičnije, ukoliko ono sobom podrazumeva fantazam odustva, imamo neminovno dodirivanje ili čak stapanje sa shizo-paranoidnim. Fantazam

${ }^{22}$ Hegel u Fenomenologiji duha govori o požudi: „,...to jednostavno Ja jeste negativna suština samostalnih momenata; i sa tim u vezi samosvest (je) sigurna u samu sebe jedino blagodareći ukidanju tog drugoga, koje se njoj predstavlja kao samostalni život; to drugo jeste požuda. Sigurna u ništavnost toga drugoga, samosvest ga za sebe predstavlja kao svoju istinu, poništava samostalni predmet i time predstavlja sebi izvesnost same sebe kao pravu izvesnost, kao takvu izvesnost koja je za nju samu postala na predmetan način“ (Hegel G. V. F., Fenomenologija duha, str. 110).

${ }^{23}$ Vidi: Freud, S., "The Ego and the Id and Other Works" in The Dissolution of the Oedipus complex: The Standard Edition of the Complete Psychological Works of Sigmund Freud. Volume XIX, 1923-1925.

${ }^{24}$ Otac, Veliki drugi ili veliko A, pojavljuje se kao nosilac simboličkog (kao delatni agens) intervencije simboličkog porekta, odnosno Zakona (Jevremović P., Lakan i psihoanaliza, str. 104). 
odsustva ogledalnog lika je gubitak svega. On sobom nosi psihološku smrt subjektiviteta. Zbog toga se insistiranje na ogledanju pojačava i struktura ostaje zauvek načeta, jezgrovno oštećena, dodirnuta samim iskrivljenjem. To iskustvo će nagoniti našeg subjekta daljim dodirivanjima, gotovo utapanjima, sa ogledalnim površinama drugih, što će ga činiti ranjivim i sklonim raz-obručavanju.

Psihoanalitički posmatrano, jedna od razvojnih funkcija majke je da se povuče onog trenutka kada dete treba da se otisne u samostalnost ili kada se nasluti težnja ka tom prevazilaženju - upravo da ne bi dolazilo do ovog teško mislivog fantazmatskog konflikta, majkaubistva. Arhetip 'majke kao žrtve' kao da svojim velikim delom leži u nužnosti njenog (voljnog ili nevoljnog) povlačenja, omogućavajući time prevazilaženje shizo-paranoidne fragmentisanosti subjektiviteta deteta. Mladićeva majka, njegov ogledalni lik, to ne dopušta. A u isto vreme ona u tom stadijumu biva sveprisutna u svojoj poziciji ogledanja. Prevazilazeći veličinu sopstvene majke, mladić bi se suočio sa fantazmatskim gubitnom funkcije brigujućeg drugog, te ostaje zaleđen pred veličinom ogledalnog lika. Ovaj pokušaj imaginarnog poništenja onoga što se dogodilo ili pomislilo (da je bolji od nje, da je mrzi što ga nije podržala i prepoznala, itd.) izraz je regresije na magijsko mišljenje.

Strah od kazne se potiskuje, ali impuls prinude je prisutan $\mathrm{u}$ ponašanju. Na taj način objašnjava se postojanje uspeha kod mladića, ali uz prisustvo prinudne simptomatologije. Tim simptomima on prerušava i umiruje desktuktivne pulzije prema brigujućem drugom, majci. Mladić se radije okreće prinudnim radnjama nego fantazmatskom uništenju kastrirajućeg odraza u ogledalnom liku. Paralelno je prisutan fantazmatski bes prema ocu, ali ne što ga nije zaštitio, već što on nije izvršio kastraciju. Edipalno posmatrano, strah prema ocu, kroz identifikaciju, gotovo nepovratno je na taj način zamenjen samosažaljenjem i pasivnom pozicijom u budućim odnosima.

Struktura, redovnost i pravila na kojima počiva psihoterapija omogućili su mladiću formiranje osećanja poverenja $\mathrm{u}$ proces $\mathrm{i}$ ostvarivanje mogućnosti za refleksiju efekta iskustva prisustva drugog, jer „nije važno prisustvo psihoterapeuta u klijentovom životu, već je 
važan efekat iskustva prisustva psihoterapeuta u klijentovom životu“،25. Mladić je pristao na psihoterapiju onda kada njegovo imaginarno jezgro, njegov narcizam nije više mogao da se održi stabilnim i bio mu je potreban supstitut za nedostajući deo sopstvenog imaginarnog jezgra, odnosno narcizma. Bio mu je potreban psihoterapeutov dovoljno dobar ${ }^{26}$ ogledalni lik. Sudbina psihoterapeuta leži u tome da je uronjen u ogledala najintimnijih priča svojih klijenata, a ta ogledala su najčešće iskrivljena $\mathrm{i}$ kao što smo videli, kod mladića svojom konkavnošću mogu da pokrenu najrazličitije procese.

Za našu tezu o konceptu narcističkih ogledalnih iskrivljenja nameće se naredno važno pitanje - Kako dolazi do iskrivljenja ogledalne površine? U psihološkom smislu ogledalna površina se formira u zavisnosti od načina ispoljavanja objekta $u$ odnosu na subjekta $u$ nastajanju. Iskustvo interakcije uvek sobom nosi određenu psihopatologiju ponašanja brigujućeg drugog. Zbog toga teza podrazumeva malu verovatnoću formiranja ravne ogledalne površine, jer bi to podrazumevalo uticaj objekta bez psihopatologije. Zbog toga verujem da uvek imamo određeni stepen iskrivljenja.

Subjekat $\mathrm{u}$ nastajanju se tokom primarnog ogledanja nalazi naspram brigujućeg drugog, koji po pretpostavci već ima konkavno ili konveksno dejstvo. Jer i sam brigujući drugi deli istu sudbinu sa svojim subjektom u nastajanju. I on sam se ogledao u iskrivljenom odrazu svog brigujućeg drugog. Dakle, ogledalni lik iskrivljenog ogledala (tj. ogledalne površine) je iskrivljen i subjekat biva izložen konkavnosti ili konveksnosti od samog početka formiranja imaginarnog jezgra. Kao što vidimo, već tokom primarnog ogledanja (unutar stadijuma ogledala) subjekat se nalazi naspram iskrivljene ogledalne površine. U predstojećem iskustvu, a pod uticajem jakih projekcija i identifikacija,

${ }^{25}$ Jevremović, P., "Psihoanaliza između krivice i tragizma Hajnca Kohuta" u Kohut, H. Psihoanaliza između krivice i tragizma: izabrani eseji, Zavod za udžbenike i nastavna sredstva, Beograd, 1999, str. 342.

${ }^{26}$ Aluzija na Vinikotov pojam - dovoljno dobra majka. 
njegova ogledalna površina se vremenom deformiše. Time se krivi i subjektov ogledalni lik koji će koristiti u svim naknadnim refleksijama sa važnim drugim.

„Subjekat u nastajanju nalazi sebe na mestu drugog (narcistički objekat malo a) poistovetivši se sa svojim ogledalnim odrazom u drugom (a')“27. Koristeći ovo određenje, u slučaju umetnutog konkavnog ili konveksnog iskrivljenja, subjekat (naglašavam - može biti subjekat u nastajanju, ili već formirani subjekat samosvesti) nalazi sebe na mestu drugog, poistovetivši se sa svojim iskrivljenim ogledalnim odrazom u drugom. Ovo mesto drugog biva iskrivljeno (konkavno ili konveksno) i kao što je rečeno, formira subjekta sa do kraja nestrukturisanim imaginarnim jezgrom.

Krećući se po sferi prelamanja, psihološki posmatrano, po samoj granici između vidljivog i nevidljivog ${ }^{28}$, mislivog i nemislivog, ostavlja se niz mogućnosti za manje ili više iskrivljena ogledala. Po sredi je još jednom priča o granici između epistemologije i ontologije $\mathrm{e}^{29}-$ o subjektu samosvesti koji teži svojoj ličnoj istini, a od koje se toliko puta otuđio.

Ogledalni lik je tu kako bismo zadobili sebe. Nemislivo na taj način postaje fantazmatski opravdano i podržano. Nesvesno biva oslikano i time odaje utisak viđenog, bliskog, gotovo doživljenog. Na taj način ogledalni lik biva simbol onoga što se fantazmatski odigrava ili je već odigrano.

Iskrivljenje se ne može razumeti kao crno ili kao belo. Ono nije dobro ili loše, ono je neminovnost, a u kom smeru će se odigrati zavisi od strukturalne predispozicije, psihopatologije i niza životnih okolnosti. Subjekat u susretu sa ogledalnim likom licem u lice gradi iskustvo sa nizom simboličkih reprezentacija i fantazama onoga što lik sobom nosi i otud imamo iskrivljenje odraznog lika.

${ }^{27}$ Jevremović, P., Lakan i psihoanaliza, str. 90.

${ }^{28}$ Vidi: Merlo- Ponti M., Vidljivo i nevidljivo.

${ }^{29}$ „Antičku ontologiju smeniće hrišćanska teologija. Učenje o biću pretočiće se u učenje o Crkvi. Jednom rečju - eklisiologija tj. učenje o Crkvi. Tako je bilo već u vreme ranih otaca. U značajnoj meri, priča o Jednom, tj. priča o istini, postaće priča o dogmi, a samim tim i o Crkvi“" (Jevremović, P., Telo, fantazam, simbol, Službeni glasnik, Beograd, 2007, str. 82). 
Još jednom ćemo se vratiti Lakanovim osnovama stadijuma ogledala. Iskrivljenje o kojem govorim, umeće se između $\mathrm{S}$ i objekta malo $a$, te refleksija a' biva izmenjena u odnosu na stepen krivine. Sferno ogledalo se nalazi između subjekta u nastajanju i slike, imaga brigujućeg drugog. Kriveći na taj način ogledalni lik u kojem se subjekat prepoznaje. S tim u vezi, na ovom mestu je važno napraviti teorijsku distinkciju između konkavnog i konveksnog ogledala i njihovih efekata. Teza se svakako oslanja na osnove fizike, ali je neophodno sve vreme razumeti da je po sredi duboko dinamski pristup koji ima za cilj razumevanje razvijanja subjektiviteta subjekta u nastajanju i kasnije implikacije za potonja ogledanja.

Konveksna ogledala nazivaju se još i ispupčena. Na sličan način kako se u fizici ova sferna ogledala koriste za rasipanje svetlosti, ispupčenje, na nivou našeg pogleda na formiranje strukture selfa subjekta, dovodi do rasipanja selfa. Ma gde se nalazio subjekat u odnosu na konveksno ogledalo, njegov ogledalni lik je uvek nestabilne forme, umanjen i uspravan (Slika 2.)

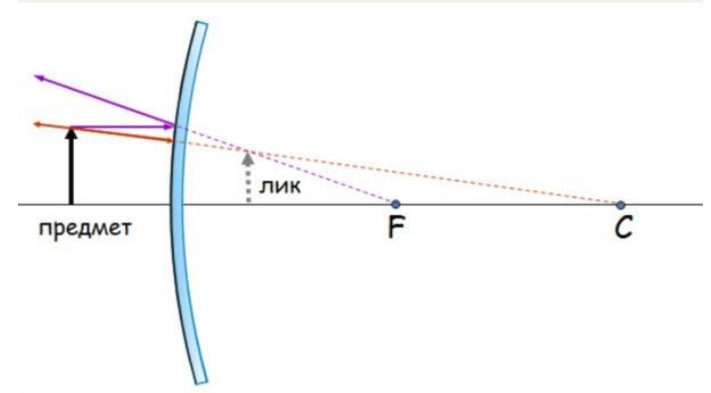

Slika 2.

Ogledalni lik je nestabilne forme, jer nastaje u produžetku razuobručenih refleksija. Jednostavno, nema tačke preseka i zraci se rasipaju u svim pravcima, što dovodi do distorzije forme. Kao i kod drugih

\footnotetext{
${ }^{30}$ Indeks pojmova: Predmet $-\mathrm{S}$, subjekat; Lik - ogledalni lik; C - centar krivine, F - žiža, fokus ogledala
} 
ogledala, jedino će veličina samog lika zavisiti od subjektove blizine ili udaljenosti od centra. U zavisnosti od kapaciteta za distanciranjem, subjekat će sebi omogućiti veći ili manji potencijal za de-centriranjem. Ipak, ovde je u svakom slučaju na snazi psihoticizam, sa paranoidnim tendencijama. Na prvom mestu psihoticizam drugog, a zatim i samog subjekta. Shizo-paranoidna pozicija imaga brigujućeg drugog dovodi do rasipanja ogledalnog lika. On iako prisutan, za subjekta ostaje psihološki neuhvatljiv. Otuđenost od sebe samog, u ovom slučaju vodi i otuđenju od drugog. Subjekat je osuđen na psihološku usamljenost i uronjenost u konveksnost narcističkih projekcija.

Takođe, uspravnost lika ukazuje na nepostojanje granice ja-drugi. U slučaju ispupčenog ogledalnog odnosa, neki subjekti su formirali jezgro sopstvenog identiteta uronjeni u postpartalne psihotične džepove brigujućih objekata, dok je kod drugih vidljiva upadljivo blaža forma narušenih granica sa drugima. Konveksno delujući drugi je rasut, haotičan, okupiran sopstvenim ogledalnim likom, zanemarujući subjekta u nastajanju koji se u njemu ogleda. On, subjekat, sve vreme biva usmeren na lik drugog u kojem se tragično ogleda. Na taj način on biva zauvek lišen stabilnosti forme sopstvenog ogledalnog lika a'.

Konkavno $^{31}$ ogledalo, s druge strane, naziva se još i izdubljeno, ili za nas terminološki adekvatnije - udubljeno. Udubljenje se formira težnjom subjekta da se približi imagu brigujućeg drugog. Dakle, udubljenost (konkavnost) u dinamskom smislu, podrazumeva da je vremenom dolazilo do pritiska na ogledalnu površinu od strane subjekta. Ta slika nije nužno bila prijatna za subjekta, ali ga je on doživljavao kao neophodnu i jedinu poznatu. Glad, praznina, žudnja. Subjekat poseduje izvesnu potrebu, želju, tendenciju ka kojoj teži u odnosu na ogledalni lik - ovo je sudbina mladića opisanog u prethodnim redovima. Ovo udubljenje se formira bilo iz potrebe da bi subjekat privukao pažnju brigujućeg drugog (koji se doživljava kao odsutan, ili u pitanju mogu biti

${ }^{31}$ Lakan je u svojim ranijim radovima govorio o odnosu između ravnog i konkavnog ogledala na nešto drugačiji način, takođe osvrćući se na narcizam. Vidi: Lacan, J., „The Two Narcissisms“ in The Seminar of Jacques Lacan Book I: Freud's Papers on Technique, 1953-1954. W.W. Norton, New York, 1988, 118-128. 
na primer depresivne tendencije) bilo zbog toga što je čeznuo za njim (anksioznost, zavisnost brigujućeg drugog). Bilo kako bilo, kod subjekta postoji stalna težnja ka objektu, jer to ontološki prazno mesto u njemu žudi da bude popunjeno. $\mathrm{Za}$ razliku od konveksnog, konkavnost omogućava usmeravanje snopa svetlosti u određenom pravcu, jer zraci svetlosti padaju na površinu i odbijaju se pod uglom koji je jednak upadnom $^{32}$.

Psihološkim rečnikom, ukoliko u stadijum ogledala imamo umetnutu konkavnost brigujućeg drugog, samo formiranje subjekta samosvesti biva usmereno u jednom od četiri moguća pravca. Te četiri pozicije konkavnog narcističkog ogledanja u zavisnosti od pozicije samog subjekta i stepena njegove samosvesti biće detaljno opisane $u$ narednim redovima.

1. Prva pozicija konkavnog narcističkog ogledanja.

Što je subjekat de-centriraniji od ogledalnog lika, to je manja njegova narcistička projekcija, a samim tim i težnja ka potpunoj identifikaciji. Kao što se u fizici objašnjava, ukoliko se predmet ogledanja nalazi na većoj udaljenosti od centra krivine, onda je ogledalni lik: stabilne forme, umanjen i obrnut (Slika 3.). U psihološkom smislu ovo znači da se slika drugog može doživeti u njegovoj stabilnosti postojanja, a da je uticaj identifikacije sa narcističkim projekcijama umeren. Subjektu nije teskobno da nađe sebe na mestu drugog, poistovetivši se sa svojim konkavnim ogledalnim likom. Važnu karakteristiku predstavlja to što je ogledalni lik obrnut, jer ilustruje doživljavanje ogledalnog lika kao ne-ja (suprotno od kao-ja) u odnosu na lični subjektivitet. Ogledalni lik može da se vidi odvojeno, nezavisno i stabilno. U prvoj poziciji konkavnog narcističkog ogledanja psihopatologija subjekta ograničava se na neurotičnu simptomatologiju, a velika je verovatnoća i da je sam objekat u kojem se subjekat narcistički ogledao, imao sličnu neurotičnu sliku.

${ }^{32}$ Prema Zakonu odbijanja. 


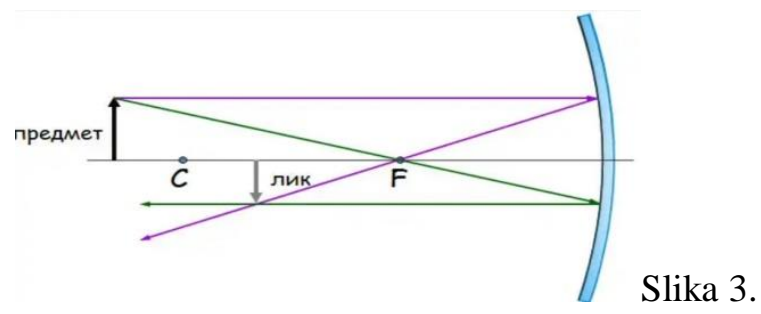

2. Druga pozicija konkavnog narcističkog ogledanja.

Što se subjekat više približava centru krivine, to važnost ogledalnog lika za njega raste, jer raste i narcistička projekcija, kao i težnja za identifikacijom - centriranjem. Ukoliko se subjekat nalazi u centru krivine (Slika 4.), ogledalni lik a' se i dalje doživljava sa stabilnom formom (tj. subjekat i dalje doživljava subjektivitet imaga drugog ${ }^{33}$ ). Ogledalni lik je sada, kao što se vidi na slici, jednak subjektu, što znači da dolazi do identifikacije sa narcističkim projekcijama, po klasičnom principu - ukoliko je subjekat projektovao dobre delove, identifikovaće se sa njima, ukoliko je projektovao loše delove, identifikovaće se sa njima. Ogledalni lik je i dalje obrnut, te subjekat u ovoj poziciji i dalje ima jasnu granicu između sopstvenog subjektiviteta i efekta ogledalnog lika. U ovoj poziciji konkavnog narcističkog ogledanja po sredi imamo narcističku simptomatologiju.

${ }^{33}$ Kao što Lakan piše u „The Two Narcissisms“, stvarna i virtuelna slika nisu ista stvar (Lacan, J., „The Two Narcissisms“ in The Seminar of Jacques Lacan Book I: Freud's Papers on Technique, 1953-1954, str. 123). Dakle, osoba se ogleda u ogledalnom liku. Realne osobe ili konkretnog brigujućeg drugog u tom smislu nema u ovoj jednačini, već samo efekat objekta koji dela svojim uticajem. Zbog toga je kategorija stabilnosti forme važna, jer omogućava subjektu da u trenutku ogledanja sa ogledalnim likom ima svest o postojanju stvarnog objekta. 


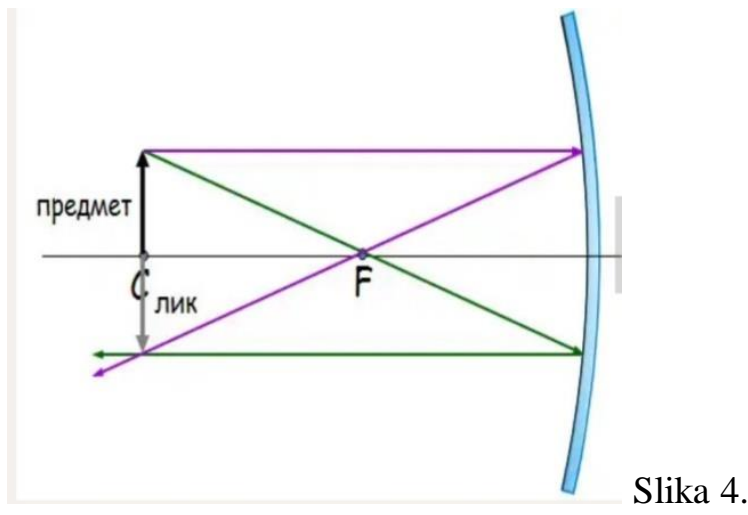

3. Tréá pozicija konkavnog narcističkog ogledanja.

U trećoj poziciji konkavnog narcističkog ogledanja subjekat se nalazi između žiže i centra krivine (Slika 5.). On je bliži ogledalnom liku, ali još uvek je moguća distanca, još uvek je moguće de-centriranje. Ogledalni lik se još uvek doživljava kao stabilan, ali ipak, sa ovim približavanjem efekat ogledalnog lika a' je porastao. Ogledalni lik je veći od subjekta, jer je po sredi preverbalna rasutost ${ }^{34}$. U ovoj poziciji, klijenti se osećaju teskobno i opterećeno ogledalnom slikom koju i dalje doživljava kao ne-ja, jer je lik i dalje okrenut i to je pozitivna okolnost ove pozicije. Subjekat ovde gotovo dotiče najdublje tačke konkavnosti, a samim tim i svoje granične strukture fragilnog selfa.

${ }^{34}$ Ili kako Jevremović opisuje: „U osnovi je prepsihološki haos“ (Jevremović, P., „Psihoanaliza između krivice i tragizma Hajnca Kohuta” u Kohut, H. Psihoanaliza između krivice i tragizma: izabrani eseji) 


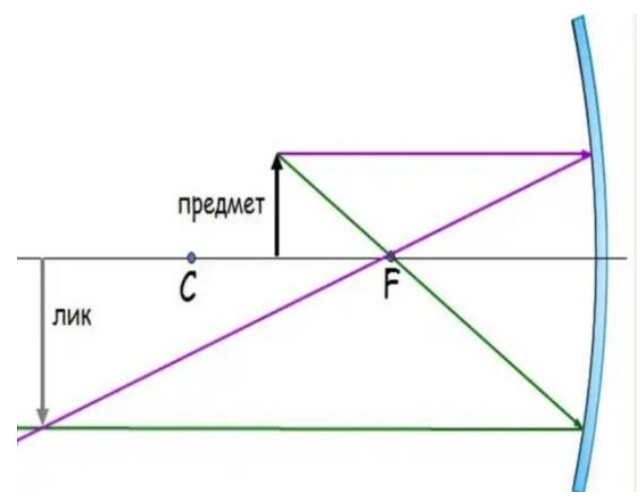

Slika 5.

4. Četvrta pozicija konkavnog narcističkog ogledanja.

Kao što smo videli, što se subjekat više približava temenu ogledala, a udaljava se od žiže, on sve više uranja u konkavnost narcističkog ogledanja sa ogledalnim likom (Slika 6.). Ogledalni lik tako gubi svoju karakteristiku stabilnosti i postaje rasute ili nestabilne forme. Ova distorzija forme uvodi subjekta u psihoticizam. Ogledalni lik je uvećan u odnosu na self subjekta, ali je takođe uvećan čime granica ne-ja (suprotno od kao-ja) prestaje da postoji. Subjekat bez odnosa ne-ja sebe izjednačava sa rasutim ogledalnim likom i nestaje u konkavnosti nestabilnog shizoidnog odraza. Klinički posmatrano, subjekat biva uronjen $\mathrm{u}$ udubljenje narcističke projekcije i u potpunosti se identifikuje sa njim, gotovo tragično.

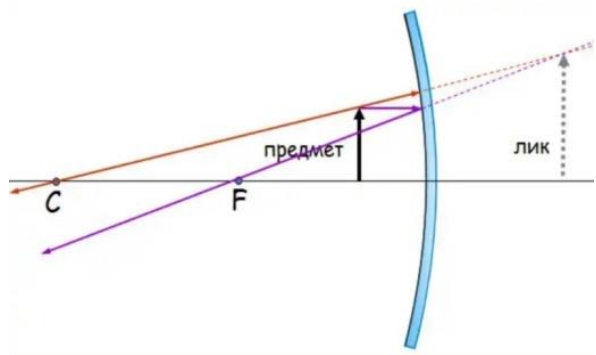

Slika 6. 
Psihoterapija je mesto susreta između klijenta i analitičara, ali i mesto susreta između subjektovog fragilnog selfa i odraznog ogledalnog lika psihoterapeuta. Klijent se ogleda u psihoterapeutovom ogledalnom liku, jer i on je drugi. On će, takođe, na početku imati efekat iskrivljenja, konkavnog narcističkog ogledanja. Bez klijenta nema psihoterapeuta, i obrnuto.

Neki bi primarno odustali. Ocenili situaciju kao beznadežnu. Kohut je govorio o narcističkom transferu i težnji klijenta za kontaktom sa analitičarem ${ }^{35}$. Nada, dakle postoji; potrebno je da psihoterapeut jača kapacitete de-centriranja kod klijenata na prvom mestu, pre svega u okviru psihoterapijskog ogledanja, a zatim i svih ostalih važnih ogledalnih odnosa koje klijent ima u svom iskustvu.

Kod konkavnog ogledanja (što je sudbina mladića o kojem je ranije u tekstu bilo reči) psihoterapijski tretman ima za cilj de-centriranje subjekta, što dovodi do umanjivanja simptomatologije. Kod konveksnog iskrivljenja, videli smo, koliko god da se subjekat udaljava ili približava ogledalnoj krivi, menja se samo intenzitet, dok kvalitet kliničke slike ostaje isti. Teorijski, napredak bi bio moguć ukoliko bi došlo do strukturalne promene - ukoliko bi došlo do poravnanja samog ogledala, tj. ogledalne površine. Ogledalna površina, videli smo, formira se u zavisnosti od načina ispoljavanja objekta $u$ odnosu na subjekta $u$ nastajanju, što znači da bi pod uticajem psihoterapije bilo potrebno da klijent kroz ogledanje $\mathrm{u}$ psihoterapeutu promeni iskustvo opisanog ogledanja. Od samog početka, ovo bi bio neizvestan i dugotrajan proces.

Zbog toga je četvrta pozicija konkavnog narcističkog ogledanja sa pozitivnijim ishodom i predikcijom od konveksnog narcističkog ogledanja. Iako na prvi pogled to možda ne deluje tako, jer zbog uvećanog ogledalnog lika klinička slika može delovati dramatičnije. Ipak, samim pomeranjem pozicije subjekta u odnosu na ogledalnu površinu

\footnotetext{
${ }^{35}$ U ovom tekstu Kohut govori o osnovama ove teze: Kohut, H., „Introspection, empathy and psychoanalysis. An examination of the relationship between mode of observation and theory". Journal of the American Psychoanalytic Association, 1959, Vol 7, 1959, str. 218.
} 
moguće je promeniti kvalitet ogledalnih refleksija. Psihoterapijskim rečnikom, jačanjem kapaciteta za distancom, proradom odsustvaprisustva i empatije brigujućih drugih, kao i radom na transferu, otvara se mogućnost za postepenim de-centriranjem od ogledalne površine, što dovodi do poboljšanja celokupne kliničke slike.

\section{LITERATURA}

Bursztein, J-G., Subjective Topology: A Lexicon, Hermann Editeurs Des Sciences Et Des Arts Sa, Paris, 2019.

Bursztein, J-G., The Unconscious, its Space-Time: Aristotle, Lacan, Poincaré, Hermann Editeurs Des Sciences Et Des Arts Sa, Paris, 2020.

Evans D., An Introductory Dictionary of Lacanian Psychoanalysis, Routledge, London, 1996.

Freud, S., "The Ego and the Id and Other Works", in The Dissolution of the Oedipus complex: The Standard Edition of the Complete Psychological Works of Sigmund Freud. Volume XIX, 1923-1925, 1924.

Friedman, M. and Tomsic, S., Psychoanalysis: Topological Perspectives: New Conceptions of Geometry and Space in Freud and Lacan, Transcript Verlag, 2017.

Greenshields, W., Writing the Structures of the Subject: Lacan and Topology (The Palgrave Lacan Series), Palgrave Macmillan, London, 2018.

Hegel, G. V. F., Fenomenologija duha, BIGZ, Beograd, 1974.

Jevremović, P., Inverzija stadijuma ogledala, u Hermeneutički triptih, Gramatik, Beograd, 2019.

Jevremović, P., Psihoanaliza i ontologija, Zavod za udžbenike i nastavna sredstva, Beograd, 1988.

Jevremović,P., Lakan i psihoanaliza, Plato, Beograd, 2000.

Jevremović, P., Telo, fantazam, simbol, Službeni glasnik, Beograd, 2007.

Jevremović, P., „Psihoanaliza između krivice i tragizma Hajnca Kohuta”, u Kohut, H. Psihoanaliza između krivice i tragizma: izabrani eseji, Zavod za udžbenike i nastavna sredstva, Beograd, 1999.

Kerneberg, P., Beyond the Reflection: The role of the mirror paradigm in clinical practice, Other Press, New York, 2007.

Klein, M., Envy and Gratitude and Other Work, A Delta Book, New York, 1977.

Kohut, H., „Introspection, empathy and psychoanalysis. An examination of the relationship between mode of observation and theory", in Journal of the American Psychoanalytic Association, 1959, Vol 7, 1959. 
Lacan, J., „The Mirror Stage as Formative of the I Function as Revealed in Psychoanalytic Experience“, in Ecrits, W. W. Norton \& Company, New York, 2006.

Lacan, J. „God and Woman's jouissance“, in Encore, W. W. Norton \& Company, New York, 1998.

Lacan, J., „The Ego in Freud's Theory and in the Tehnique of Psychoanalysis“, in The Seminar of Jacque Lacan, Book II, . Cambridge, 1988.

Lacan, J., „The Ethics of Psychoanalysis“, in The Seminar of Jacques Lacan: Book VII, 1959-60, Routledge, London, 1992.

Lacan, J., „The Two Narcissisms“, in The Seminar of Jacques Lacan Book I:

Freud's Papers on Technique, 1953-1954. W.W. Norton, New York, 1988.

Merlo-Ponti M., Vidljivo i nevidljivo, Akademska knjiga, Novi Sad, 2012.

Ragland, E. and Milovanovic, D., Lacan: Topologically Speaking, Other Press, New York, 2004.

Winnicott, D. W., Mirror-role of the mother and family in child development, in Playing and Reality, Psychology Press, Hove, 2005.

MAJA MILIĆ

Belgrade

\title{
BASIC THESES BEHIND THE CONCEPT OF NARCISSISTIC DISTORTION
}

\begin{abstract}
This paper offers the basic theses behind the concept of narcissistic distortion, which can take place in two directions - the paper explains subject formation and experience in so-called concave and convex narcissistic mirroring. The theory proposed in this paper largely relies on Lacan's mirror stage, and on his contribution to subject's development of self-consciousness through constitutive-imaginary dimensions of subjectivity. In cases of inserted concave or convex distortion, the subject locates themselves in the place of the Other, by identifying themselves with their own distorted mirror image in the Other. These distortions influence subject formation in a very concrete manner, carrying over the predisposition for certain instabilities in latter mirroring. The paper is illustrated with a case study aimed at easier understanding of the approach offered in it. It also provides a critical reflection on the possibility of plane
\end{abstract}


mirror formation, as well as a detailed designation of convex distortion and four positions of concave narcissistic distortion.

Keywords: psychoanalysis, Lacan, mirror stage, narcissistic mirroring distortion

Primljeno: 23.2.2020.

Prihvaćeno: 6.5.2020. 